\title{
RAMBATAN GELOMBANG DI PANTAI MALALAYANG II
}

\author{
(Wave Propagates in Malalayang II Coastal)
}

\section{Exer Bambulu1*, Hermanto W.K. Manengkey ${ }^{1}$, Royke M. Rampengan'}

1. Program Studi Ilmu Kelautan, Fakultas Perikanan dan Ilmu Kelautan, Universitas Sam Ratulangi Manado.

*e-mail : exerbambulu@gmail.com

The aims of this research are to describe the topography of Malalayang Dua Coast in the form of bathymetric chart and to analyze wave activities and its relation to seafloor topography. Water depth of Malalayang Dua Coast ranged between 1-31.8m. Wave refraction in North Wind Season started at $21.23 \mathrm{~m}$ depth at high tide and $1.96 \mathrm{~m}$ depth at low tide when enter shallow sea while in First Transition Season wave friction to seafloor started at $20.5 \mathrm{~m}$ depth at high tide and $1.85 \mathrm{~m}$ depth at low tide, then when the waves start to contact with the seafloor in Second Transition Season, the refraction start at $20.11 \mathrm{~m}$ depth at high tide and $1.96 \mathrm{~m}$ depth at low tide. The difference of distance line when the wave influenced seafloor cause difference distance to the coast line as well as distance between depth line of transition and shallow seas.

Keywords : waves, coastal, Malalayang waters, refraction

Penelitian ini dilakukan dengan tujuan untuk mendeskripsikan topografi dasar perairan Pantai Malalayang II dalam bentuk peta batimetri dan menganalisis aktivitas gelombang dalam kaitannya dengan topografi dasar perairan. Kedalaman perairan Pantai Malalayang II telah berhasil ditelaah serta dianalisis dengan hasil kedalaman berkisar antara 1-31,8 $\mathrm{m}$. Refraksi dimulai pada kedalaman $21,23 \mathrm{~m}$ saat pasang dan memasuki laut dangkal pada kedalaman $1,96 \mathrm{~m}$ saat surut di musim Utara, sedangkan di musim Peralihan I gelombang mulai bergesekan dengan dasar perairan dimulai pada kedalaman 20,54 m disaat pasang dan memasuki laut dangkal di kedalaman $1,85 \mathrm{~m}$ saat surut, kemudian di saat gelombang mulai bersentuhan dengan dasar perairan di musim Peralihan II mulai dari kedalaman 20,11 m disaat pasang dan saat memasuki laut dangkal dimulai pada kedalaman $1,96 \mathrm{~m}$ saat surut. Perbedaan garis kedalaman saat gelombang mempengaruhi dasar perairan ini menyebabkan perbedaan jarak dari garis pantai dan juga jarak di antara garis kedalaman laut transisi dan laut dangkal.

Kata kunci : gelombang, pantai, perairan Malalayang, refraksi

\section{PENDAHULUAN}

Daerah pantai diketahui sebagai ruang peralihan antara daratan dan lautan. Menurut Sulaiman dan Soehardi (2008), daerah pantai merupakan sistem antara daratan dan lautan yang saling berinteraksi, dimana ke arah darat masih dipengaruhi oleh sifat-sifat dari laut seperti angin laut, pasang surut, dan perembesan air laut, sedangkan ke arah laut masih dipengaruhi oleh proses-proses alami yang terjadi di wilayah darat seperti sedimentasi yang dibawah aliran sungai maupun aktivitas manusia. Triatmodjo (2011) menjelaskan perubahan bentuk pantai dipengaruhi oleh faktor-faktor Hidro-oseanografi, salah satunya yaitu gelombang laut yang merambat ke daerah pantai. 
Rambatan gelombang mendekati garis pantai sangat ditentukan oleh kondisi topografi dasar perairan di mana gelombang merambat. Menurut Stewart (2008) kecepatan gelombang pada perairan dangkal merupakan fungsi dari kedalaman perairan. lebih lanjut dijelaskan bahwa variasi kedalaman di perairan dangkal merupakan faktor penentu terhadap pemusatan dan penyebaran energi gelombang. Pemusatan dan penyebaran energi gelombang di pantai merupakan salah satu faktor pemicu terjadinya erosi dan abrasi pantai. Abrasi pantai merupakan suatu proses pengikisan yang terjadi di bibir pantai yang diakibatkan oleh aksi gelombang dan arus susur pantai, sedangkan erosi pantai merupakan proses mundurnya garis pantai dari posisi semula yang dikarenakan adanya angkutan sedimen litoral sepanjang pantai sehingga mengakibatkan berpindahnya sedimen dari suatu tempat ke tempat lainnya.

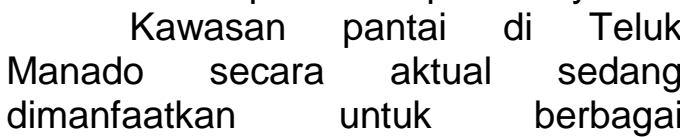
kepentingan. Salah satunya adalah pemanfaatan ruang pemukiman nelayan di Kelurahan Malalayang II. Keberadaan kawasan ini berada pada bagian daratan di pinggiran pantai dan secara langsung mendapat pengaruh dari aksi laut terutama gelombang. Pemahaman mengenai gelombang dan corak dasar perairan (Topografi) sangat penting untuk dikaji. Hal ini dilakukan karena adanya kaitan antara pemahaman tersebut dengan pemanfaatan kawasan Pantai Malalayang II. Berdasrkan hal tersebut maka penelitian ini bertujuan: 1). Mendeskripsikan topografi dasar perairan Pantai Malalayang II dalam bentuk peta batimetri, 2). Menentukan karakteristik gelombang pada kawasan perairan Pantai Malalayang II, 3). Menganalisis gelombang dalam kaitannya dengan topografi dasar perairan.

\section{METODE PENELITIAN}

Penelitian ini dilaksanakan dengan penerapan metode deskriptif (Nazir, 1983) yaitu dengan pelaksanaan survei pantai secara rinci untuk menjawab permasalahan yang ditetapkan. Survei pantai yang diterapkan diarahkan untuk mengungkapkan topografi dasar perairan pantai melalui kegiatan pengukuran untuk keperluan menghasilkan peta batimetri. Selain itu, pada penelitian ini juga dilaksanakan pengukuran pasang surut selama 39 jam dalam kaitannya dengan pengolahan data batimetri, pengukuran variabel gelombang secara langsung, dan pengolahan variabel gelombang seperti arah penjalaran, tinggi, periode, dan panjang gelombang berdasarkan data sekunder.

\section{Lokasi Penelitian}

Kegiatan penelitian sesuai dengan tujuan yang telah ditetapkan dilaksanakan di perairan Pantai Malalayang II dengan posisi geografis berada sekitar $1^{\circ} 27^{\prime} 33^{\prime \prime}-1^{0} 27^{\prime} 35^{\prime \prime}$ LU dan $124^{\circ} \quad 48^{\prime} \quad 22^{\prime \prime}-124^{\circ} \quad 48^{\prime} \quad 25^{\prime \prime}$ BT. Kedudukan lokasi penelitian seperti yang diperlihatkan pada Gambar 1 berikut ini.

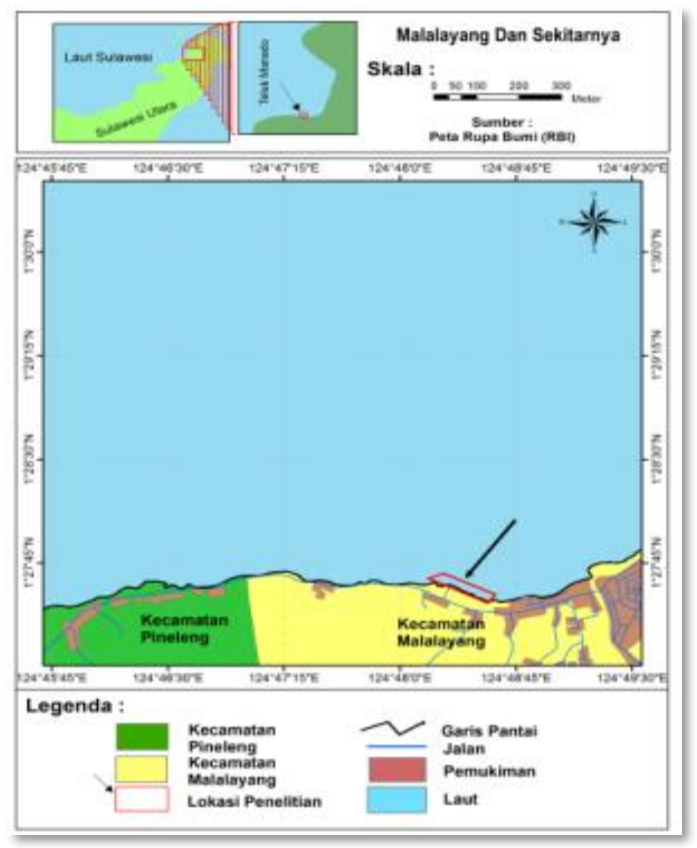

Gambar 1. Peta lokasi penelitian. 
Tabel 1. Peralatan penelitian.

\begin{tabular}{|c|c|}
\hline Bahan dan Alat & Kegunaan \\
\hline GPS & Penentu posisi \\
\hline Fish finder & Mengukur \\
\hline & Kedalaman \\
\hline Stop watch & Mengukur Waktu \\
\hline Perahu & Sarana Apung \\
\hline Alat tulis & Pencatatan Data \\
\hline Palem pasut & $\begin{array}{l}\text { Pengukur Muka } \\
\text { Laut }\end{array}$ \\
\hline $\begin{array}{l}\text { - Komputer, } \\
\text { perangkat } \\
\text { Lunak }\end{array}$ & $\begin{array}{l}\text { Pengolah Kata, } \\
\text { Data dan Grafik }\end{array}$ \\
\hline Printer & $\begin{array}{l}\text { Mencetak hasil } \\
\text { olahan dan analisis } \\
\text { data }\end{array}$ \\
\hline 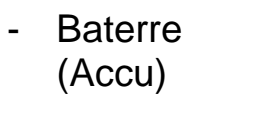 & $\begin{array}{l}\text { Sumber Tenaga } \\
\text { Fish Finder } \\
\text { dan GPS }\end{array}$ \\
\hline
\end{tabular}

\section{Prosedur Survei dan Pengukuran}

Kegiatan survei dilaksanakan dilapangan pada bulan Mei 2017 saat fase umur bulan purnama. Pemilihan fase umur bulan ini dilamdasi oleh keperluan pemeruman sampai pada daerah dekat dengan garis pantai. kegiatan ini membutuhkan pelaksanaan kegiatan pemeruman pada kondisi pasang tertinggi yang memungkinkan pemeruman sampai pada daerah dangkal di perairan pantai.

\section{Pengukuran Kedalaman}

Pengukuran untuk kedalaman dikerjakan dengan menggunakan alat bantu Fish Finder dan GPS (Global Positioning System).

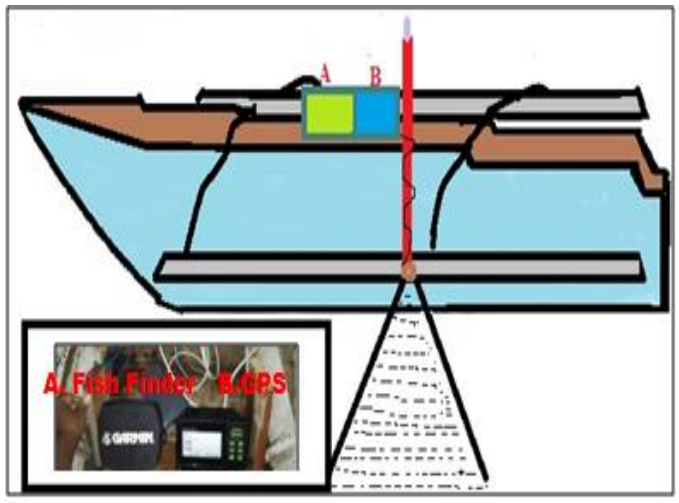

Gambar 2. Peralatan untuk perum.
Transduser peralatan Fish Finder diletakan pada bagian samping tengah sarana apung atau di perahu survei dengan posisi ujung terbawahnya sedikit berada di atas lunas perahu. Antena GPS dipasang di perahu tepat di atas dari peralatan transduser diletakkan. Pemasangannya akan lebih baik apabila menggunakan sebuah tongkat kayu yang didirikan tegak lurus di perahu. Bagian bawah tongkat yang berada di dalam air dipasangi transduser dari Fish Finder, sedangkan ujung yang sebelah atas dipasangi antena GPS diperlihatkan pada Gambar 2. selama pengukuran kedalaman berlangsung, juga dilakukan pengukuran pasang surut dengan interval 10 menit untuk mendapatkan data kedalaman yang lebih rinci.

\section{Pengukuran Gelombang}

Pengukuran untuk gelombang dilakukan pada palem pasang surut dan di garis pantai pada satu titik yang ditetapkan. Data gelombang yang diukur yaitu tinggi gelombang $(\mathrm{H})$, dilakukan pada palem pasang surut dengan mengamati puncak dan lembah dari gelombang saat muka air melewati palem pasut. Periode gelombang ( $T$ ), diukur dengan menggunakan stopwatch yaitu dengan mencatat selang waktu dua puncak gelombang yang berurutan melewati titik amatan. Frekuensi gelombang $(F)$, diperoleh dengan menghitung banyaknya hempasan gelombang di pantai dalam waktu 1 menit.

Pengukuran data gelombang secara langsung hanya dapat dilakukan dalam skala waktu yang sangat singkat. Untuk mendapatkan informasi karakteristik gelombang yang lebih mewakili perairan di mana survei dilakukan, maka digunakan juga data sekunder gelombang di Teluk Manado. adapun data sekunder gelombang yang digunakan diperoleh dari situs ECMWF (European Centre Mid-Range Weather Forecast). Variabel - variabel gelombang yang digunakan adalah 
arah rambatan gelombang, tinggi gelombang signifikan, $\left(H_{s}\right.$ atau $\left.H_{1 / 3}\right)$ dan periode gelombang $(\mathrm{T})$. Menurut DISHIDROS (1984), musim Utara terjadi dari bulan Desember-Februari dan dilanjutkan pada musim Peralihan I yaitu dari bulan Maret-Mei. Bulan JuniAgustus merupakan musim Selatan, sedangkan pada musim Peralihan II terjadi di bulan September-November.

Lebih lanjut pada musim-musim yang disebutkan di atas, keadaan angin dan curah hujan berbeda yaitu di musim Utara angin bertiup tidak teratur dan merupakan periode terbanyak, sedangkan untuk musim Peralihan I, keadaan angin tidak berpengaruh cukup besar dikarenakan angin yang bertiup sangat lemah dan teratur, akan tetapi sekali waktu keadaan bisa berubah-ubah. Untuk keadaan saat musim Peralihan II dan Selatan anginnya bervariasi, berubah-ubah arah dan kecepatannya.

\section{Model dan Cara Analisis Data}

Dari hasil pengukuran yang diperoleh dari lokasi survei diolah dalam bentuk tabel, grafik serta dalam bentuk gambar. Pembuatan tabel, grafik dan gambar dilakukan dengan menggunakan bantuan dari seperangkat alat komputer dengan dilengkapi program aplikasi Excel, Argis 10.3, dan Surfer.

Pengerjaan pengolahan dan analisis data kedalaman laut pada tiap titk penarikan contoh dikerjakan mengikuti setiap tahapan pengolahan sebagai berikut:

> Pencatatan data kedalaman yang terbaca oleh Fish Finder pada setiap titik fix sebagaimana ditunjukkan oleh GPS beserta posisinya kedalam lembar isian dan dikelompokkan menurut waktu pencatatan pada setiap jalur pemeruman.

Hasil pengamatan pasang surut selama kegiatan pengukuran kedalaman, dikelompokkan sesuai waktu untuk dilaksanakan koreksi kedalaman.
Hasil kedalaman terukur selanjutnya dikoreksi dengan hasil pengukuran pasut dan kedalaman pemasangan transduser. Kedalaman terkoreksi dihitung dengan menggunakan formula sederhana sebagai berikut :

$$
\mathrm{H}_{\text {plot }}=\mathrm{H}_{\text {ukur }}+\mathrm{H}_{\mathrm{T}} \pm \mathrm{H}_{\text {Pas }}
$$

Keterangan:

$$
\begin{aligned}
\mathrm{H}_{\text {plot }}= & \text { Kedalaman terkoreksi } \\
\mathrm{H}_{\text {ukur }}= & \text { Kedalaman terukur selama } \\
& \text { pengukuran } \\
\mathrm{HT}= & \text { Kedalaman tranduser } \\
\mathrm{H}_{\text {pas }}= & \text { Bedaantara muka laut rata } \\
& \text { rata dengan level muka air } \\
& \text { laut saat pemeruman }
\end{aligned}
$$

Nilai muka laut rata-rata diperoleh dari pencatatan data pasang surut setiap jam selama 39 jam. Hasil pencatatan data pasang surut tersebut diolah dengan menerapkan metode Filter Doodson seperti diuraikan oleh (Suyarso, 1989) sebagai berikut :

$$
\mathrm{X}_{\mathrm{t}}=\frac{1}{30} \sum_{d=-19}^{d=19} F(d) H(T+d), d \neq 0
$$

Keterangan :

$$
\begin{aligned}
\mathrm{X}_{\mathrm{t}}= & \text { Muka laut rata-rata } \\
\mathrm{T}= & \text { Waktu tengah (jam 12.00) } \\
\mathrm{F}(\mathrm{d})= & (2,1,1,2,0,1,1,0,2,0,1,1, \\
& 0,0,1,0,1)
\end{aligned}
$$

Data periode gelombang yang diperoleh dari hasil pegukuran, digunakan untuk memperoleh nilai panjang gelombang (L). Hasil tersebut dilakukan karena panjang gelombang tidak dapat diukur langsung di perairan, sehingga diperoleh melalui hubungan antara panjang gelombang dan periode gelombang. Lebih lanjut dalam perhitungan untuk memperoleh nilai panjang gelombang laut dalam dan laut dangkal dilakukan dengan menggunakan perhitungan menurut Triatmodjo (2011). Formula yang dimaksud yaitu sebagai berikut : 
Untuk panjang gelombang laut dangkal yaitu :

$\mathrm{L}=\sqrt{\operatorname{g.d}} . \mathrm{T}$

Keterangan :

$\mathrm{L}$ = Panjang gelombang

$\mathrm{G}=$ Gravitasi $9.81 \mathrm{~m} / \mathrm{s}^{2}$

$\mathrm{T}=$ Periode gelombang

dan panjang gelombang pada laut dalam yaitu :

$L=1,5625 . T^{2}$

\section{HASIL DAN PEMBAHASAN}

Pelaksanaan survei pengukuran di Pantai Malalayang II dilaksanakan pada tanggal 25-27 Mei 2017. Pengukuran dilakukan untuk memenuhi tujuan yang ditetapkan dengan metode yang telah dikemukakan, serangkaian penelitian dikerjakan.

\section{Batimetri Perairan Malalayang II}

Pengukuran dan pengambilan data kedalaman di pesisir Kelurahan Malalayang II dari perairan dangkal ke arah laut. Kedalaman perairan di wilayah penelitian selanjutnya dibuat dalam bentuk peta batimetri. Diperlihatkan pada Gambar 3 dan 4.

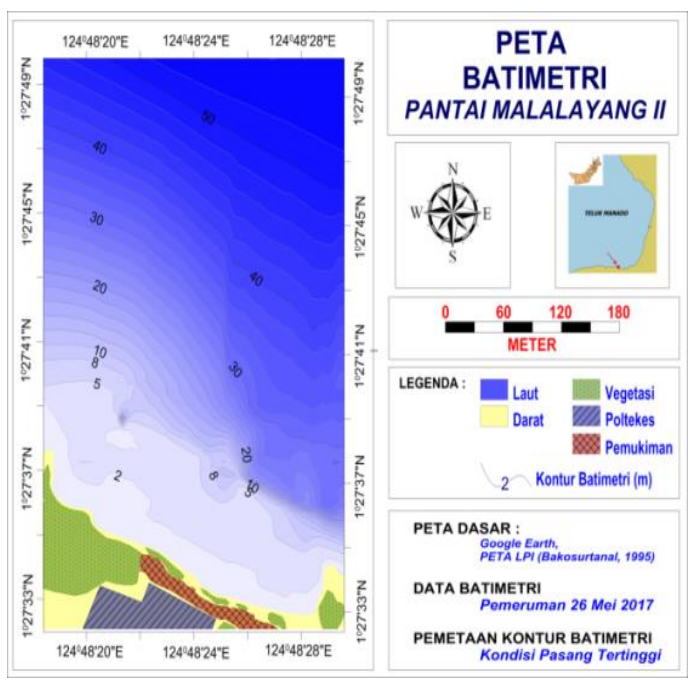

Gambar 3. Kedalaman perairan pada saat muka air tertinggi.

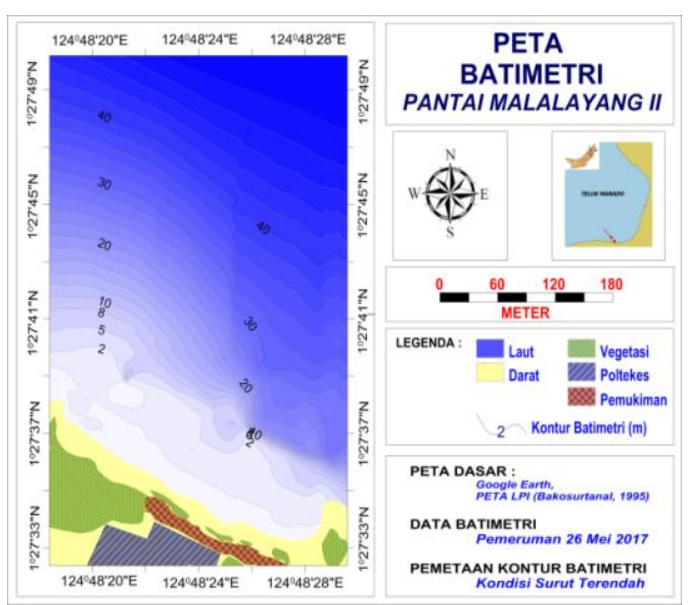

Gambar 4. Kedalaman perairan pada saat surut terendah.

\section{Hasil Analisis Data Gelombang (Data ECMWF)}

Hasil pengolahan dan analisis data arah datang gelombang di perairan Teluk Manado (Gambar 5) secara aktual memperlihatkan pengaruh pemusatan angin dari Utara, Timur Laut, Barat dan Barat Laut. gelombang yang menerpa kawasan pantai Malalayang II dikategorikan dalam beberapa arah menurut keadaan musim yaitu musim Utara, Peralihan I, Selatan, dan Peralihan II. Arah datang gelombang tersebut diuraikan disetiap musim ditampilkan pada Tabel 2.

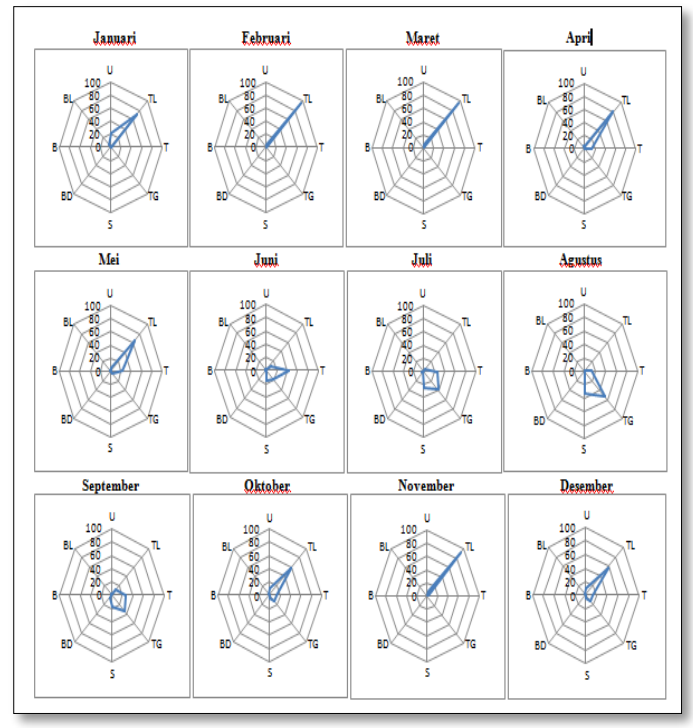

Gambar 5. Arah datang gelombang pada setiap bulan (Data ECMWF 20122016). 
Tabel 2. Persentasi arah datang gelombang di setiap musim (Data ECMWF 20122016).

\begin{tabular}{lrrrr}
\hline \multirow{2}{*}{ Arah } & \multicolumn{5}{c}{ Musim } \\
\cline { 2 - 5 } & Utara & Peralihan I & Selatan & Peralihan II \\
\hline U & $11,74 \%$ & $4,35 \%$ & $1,44 \%$ & $6,11 \%$ \\
TL & $85,62 \%$ & $79,78 \%$ & $5,30 \%$ & $53,31 \%$ \\
T & $0,00 \%$ & $11,34 \%$ & $26,86 \%$ & $12,00 \%$ \\
TG & $0,00 \%$ & $1,48 \%$ & $36,33 \%$ & $14,61 \%$ \\
S & $0,00 \%$ & $0,88 \%$ & $24,20 \%$ & $7,39 \%$ \\
BD & $0,00 \%$ & $0,00 \%$ & $1,47 \%$ & $2,21 \%$ \\
B & $0,00 \%$ & $0,17 \%$ & $2,95 \%$ & $1,80 \%$ \\
BL & $2,64 \%$ & $2,00 \%$ & $1,45 \%$ & $2,57 \%$ \\
Jumlah & $100,00 \%$ & $100,00 \%$ & $100,00 \%$ & $100,00 \%$ \\
\hline
\end{tabular}

Berdasarkan hasil perhitungan didapat nilai persentasi arah datang gelombang yang terjadi di musim Utara yaitu dari Timur Laut dengan persentasinya $85,62 \%$ dan merupakan persentasi terbesar dari keseluruhan arah datang gelombang di musim tersebut. Demikian halnya di musim Peralihan II arah datang gelombang masih dari arah Timur Laut dengan persentasi $79,78 \%$ dan merupakan persentasi terbesar dari arah datang gelombang yang terjadi di musim Peralihan I, sedangkan musim Selatan arah datang gelombang hanya sebagian kecil atau sekitar $11 \%$ yang mengarah ke perairan pantai Malalayang II. Lebih lanjut pada musim tersebut arah datang gelombang berasal dari Tenggara dengan persentasi $36 \%$ dan merupakan persentasi terbesar dari keseluruhan arah datang gelombang yang terjadi pada musim Selatan. Berikutnya di musim Peralihan II arah datang gelombang berasal dari Timur Laut dengan persentasi $53,31 \%$ dan merupakan persentasi terbesar dari semua arah datang gelombang yang terjadi di musim tersebut. Selain data gelombang hasil pengukuran dan data gelombang dari ECMWF yang diuraikan, dilakukan juga pengambilan data pasang surut selama 39 jam dimulai pada pukul 17:00 WITA 25 Mei sampai pukul 07:00 WITA 27 Mei 2017.
Dari hasil pengukuran pasang surut diperoleh beberapa elevasi muka air laut yang didapat dilihat pada Tabel 3. Keberadaan karakteristik pantai Malalayang II yang secara aktual bisa dilihat saat penelitian sangatlah beragam menurut tingkat kedalaman perairan. Di daerah pantai pada kedalaman perairan 1-2 m terdiri dari bebatuan kerikil dan pasir berlumpur, sedangkan di kedalaman $>2-7 \mathrm{~m}$ terdapat rataan terumbu walaupun hanya sebagian kecil. Lebih lanjut di daerah pantai Malalayang II dapat dilihat dengan kasat mata bahwa sebagian wilayah telah mengalami abrasi pantai dan deposisi yang diakibatkan faktor oseanografi di wilayah pantai tersebut. Bagian Barat pantai Malalayang II topografinya semakin landai dan hal ini disebabkan oleh perpindahan sedimen dari darat menjorok ke laut yang diakibatkan oleh arus susur pantai, sedangkan di sebelah Timur topografinya semakin dalam karena disebabkan oleh deposisi ke arah daratan.

Tabel 3. Hasil data pasut di perairan pantai Malalayang II.

\begin{tabular}{clr}
\hline No & Muka air laut & $\begin{array}{c}\text { Data hasil } \\
\text { analisis }\end{array}$ \\
\hline 1 & Tunggang Pasut & 238 \\
2 & M S L & 139,7 \\
3 & H H W L & 265 \\
4 & L L W L & 27 \\
\hline
\end{tabular}




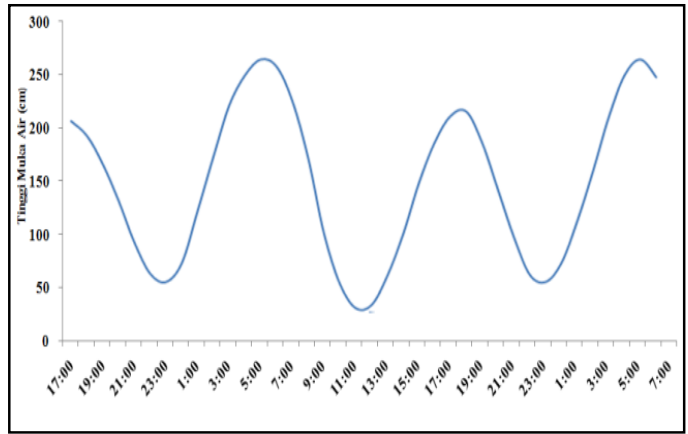

Gambar 6. Hasil pengamatan pasut selama 39 jam.

Keberadaan karakteristik pantai Malalayang II yang secara aktual bisa dilihat saat penelitian sangatlah beragam menurut tingkat kedalaman perairan. Di daerah pantai pada kedalaman perairan 1-2 m terdiri dari bebatuan kerikil dan pasir berlumpur, sedangkan di kedalaman $>2-7 \mathrm{~m}$ terdapat rataan terumbu walaupun hanya sebagian kecil. Lebih lanjut di daerah pantai Malalayang II dapat dilihat dengan kasat mata bahwa sebagian wilayah telah mengalami abrasi pantai dan deposisi yang diakibatkan faktor oseanografi di wilayah pantai tersebut. Bagian Barat pantai Malalayang II topografinya semakin landai dan hal ini disebabkan oleh perpindahan sedimen dari darat menjorok ke laut yang diakibatkan oleh arus susur pantai, sedangkan di sebelah Timur topografinya semakin dalam akibat proses deposisi ke arah daratan.

Topografi dasar perairan sangat mempengaruhi kerja gelombang yang datang mengarah ke daerah pantai, hal ini diakibatkan kontur kedalaman yang berbeda-beda. Perbedaan jarak dimana gelombang mulai memasuki daerah laut transisi berbeda di bagian Barat dan Timur. Lebih lanjut di bagian Barat mengalami peredaman energi gelombang yang jauh lebih besar dibandingkan peredaman energi gelombang pada bagian Timur sebelum mencapai garis pesisir.

Rambatan gelombang dari laut dalam hingga sampai ke garis pantai dipengaruhi oleh pasang surut air laut di daerah tersebut. Jangkauan rambatan gelombang pada saat surut tidak bisa sampai ke garis pantai, karena ada sebagian dasar perairan sudah terdedah ke permukaan, sehingga gelombang telah pecah sebelum mencapai garis pesisir. Saat pasang tertinggi rambatan gelombang yang dapat mencapai garis pesisir dengan terlebih dahulu melewati wilayah transisi dan laut dangkal, sehingga dapat mempengaruhi bentuk pantai.

Gambar 7, 8, dan 9 menampilkan peta rambatan gelombang ke pantai Malalayang II saat kondisi surut, pada musim Utara, Peralihan I, dan peralihan II. Gelombang yang merambat dari laut dalam saat memasuki laut transisi dan dangkal mengalami refraksi gelombang akibat bersentuhan dasar perairan. Refraksi yang terjadi dimulai dari kedalaman 19,21 m dengan panjang gelombang 38,41 $\mathrm{m}$ dan periode 7,02 detik. Di perairan dangkal dimulai pada kedalaman 1,92 $\mathrm{m}$ dengan panjang gelombang 19,02 $\mathrm{m}$ dan periodenya 8,76 detik, sedangkan di daerah lain yang nilainya $0 \mathrm{~m}$ yaitu wilayah terdedah atau kering pada surut terendah saat musim Utara. Keberadaan garis kedalaman perairan pada saat gelombang mulai bergesekan dengan dasar perairan (gelombang laut transisi) dan garis kedalaman gelombang laut dangkal memiliki jarak yang berbeda-beda.

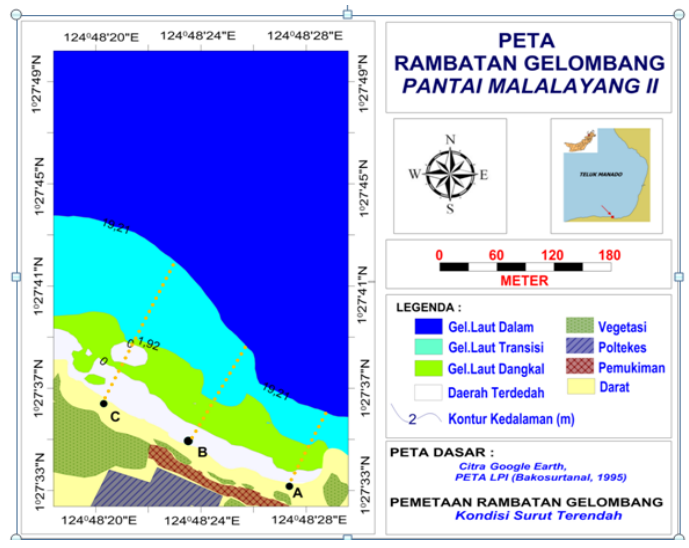

Gambar 7. Rambatan gelombang saat surut terendah (LWL) musim utara (Data ECMWF 2012-2016). 
Pengukuran jarak ini dilakukan dengan menarik garis dengan arah tegaklurus garis pesisir. Seperti ditampilkan pada tabel 4 pada profil A sejauh $44 \mathrm{~m}$ dan $98 \mathrm{~m}$, profil B sejauh $56 \mathrm{~m}$ dan $144 \mathrm{~m}$, profil $\mathrm{C}$ sejauh $80 \mathrm{~m}$ dan $205 \mathrm{~m}$ saat surut terendah (LWL) di musim Utara. Dari ke tiga profil penariakan jarak rata-rata gelombang laut transisi ke garis pesisir sejauh 149 m. (Gambar 7).

Rambatan gelombang saat memasuki laut transisi di musim Peralihan I saat surut terendah dimulai di kedalaman 18,54 $\mathrm{m}$ dengan panjang gelombang $37,09 \mathrm{~m}$ dan periode 6,90 detik, sedangkan di perairan dangkal panjang gelombangnya $18,37 \mathrm{~m}$ di kedalaman 1,85 $\mathrm{m}$ dengan periode 8,61 detik. Berdasarkan hasil pengukuran jarak antara laut transisi dan laut dangkal didapat perbedaan jarak di setiap profil yaitu profil A sejauh $49 \mathrm{~m}$ dan $103 \mathrm{~m}$, profil $B$ sejauh $48 \mathrm{~m}$ dan $140 \mathrm{~m}$, profil $\mathrm{C}$ sejauh $73 \mathrm{~m}$ dan $203 \mathrm{~m}$. Dari ke tiga profil penarikan jarak di atas didapat nilai rata-rata gelombang laut dankal ke garis pesisir adalah sejauh 56,66 $\mathrm{m}$ dan jarak rata-rata gelombang laut transisi ke garis pesisir yaitu sejauh 148,66 m (Gambar 8). Di musim Peralihan II saat surut terendah gelombang mulai mengalami proses refraksi di kedalalman 19,59 m dengan periode 7,09 detik dan panjang gelombang 39,18 m, sedangkan di laut dangkal dimulai pada kedalaman 1,96 $\mathrm{m}$ dengan panjang gelombang $19,40 \mathrm{~m}$ dan periode 8,85 detik. Pada musim Peralihan II juga dilakukan pengukuran jarak rambatan gelombang dari laut transisi dan dangkal ke garis pantai di setiap profil memiliki perbedaan yaitu profil A sejauh $51 \mathrm{~m}$ dan $110 \mathrm{~m}$, profil $B$ sejauh $56 \mathrm{~m}$ dan $144 \mathrm{~m}$, profil $\mathrm{C}$ sejauh $172 \mathrm{~m}$ dan $195 \mathrm{~m}$ dan jarak rataratanya gelombang laut transisi ke garis pesisir sejauh 59,66 m dan jarak ratarata gelombang laut dangkal ke garis pesisir yaitu sejauh 149,66 m. Jarak garis kedalaman antara gelombang laut transisi dan laut dangkal di musim Utara ke garis pesisir saat muka laut
Tabel 4. Jarak rambatan gelombang dari laut transisi ke garis pesisir di saat surut terendah (Data ECMWF 20122016).

\begin{tabular}{lccccc}
\hline $\begin{array}{l}\text { Kategori } \\
\text { Musim }\end{array}$ & $\begin{array}{c}\text { P } \\
\text { L.D } \\
\text { m }\end{array}$ & $\begin{array}{l}\text { L.T } \\
\mathrm{m}\end{array}$ & $\begin{array}{l}\text { L.D } \\
\text { dan } \\
\text { L.T } \\
\text { m }\end{array}$ & D.T \\
\hline Musim & A & 44 & 98 & 54 & 16 \\
Utara & B & 56 & 144 & 88 & 20 \\
Musim & C & 80 & 205 & 125 & 34 \\
Peralihan & A & 49 & 103 & 54 & 17 \\
I & B & 48 & 140 & 92 & 21 \\
Musim & C 73 & 203 & 130 & 38 \\
Peralihan & A & 51 & 110 & 59 & 18 \\
II & B 56 & 144 & 88 & 19 \\
Rata-rata & C 72 & 195 & 123 & 34 \\
\hline Keterangan & & 149 & 90 & 20 \\
\hline
\end{tabular}

Keterangan :

$\mathrm{P}=$ Profil L.D = Laut Dangkal, LT

$=$ Laut Transisi D.T, = Daerah Terdedah

tertinggi di beberapa titik menunjukkan perbedaan jarak. Perbedaan jarak tersebut seperti dijelaskan pada Tabel 5 bahwa profil A sejauh $19 \mathrm{~m}$ dan $92 \mathrm{~m}$, profil B sejauh $20 \mathrm{~m}$ dan $130 \mathrm{~m}$, profil $\mathrm{C}$ sejauh $28 \mathrm{~m}$ dan $172 \mathrm{~m}$ di musim utara saat pasang tertinggi.

Berdasarkan ke tiga profil penarikan jarak tersebut diketahui bahwa jarak rata-rata gelombang laut dangkal ke garis pesisir sejauh 22,33 $\mathrm{m}$, dan jarak rata-rata gelombang laut transisi ke garis pesisir sejauh 131,33 $\mathrm{m}$.

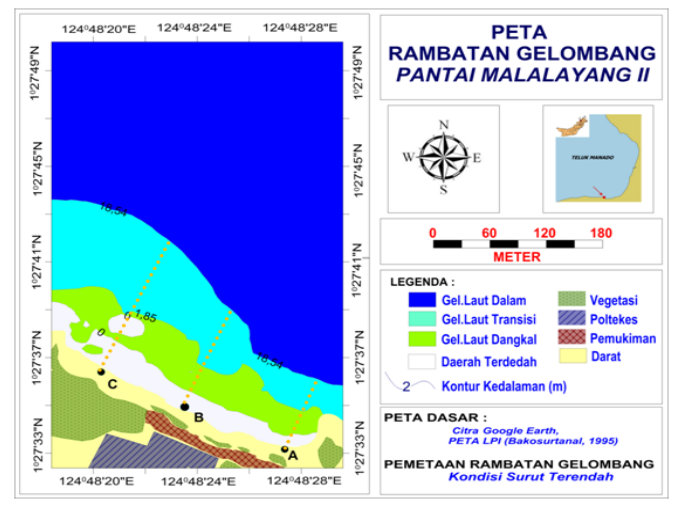

Gambar 8. Rambatan gelombang saat surut terendah (LWL) musim peralihan I (Data ECMWF 2012-2016). 


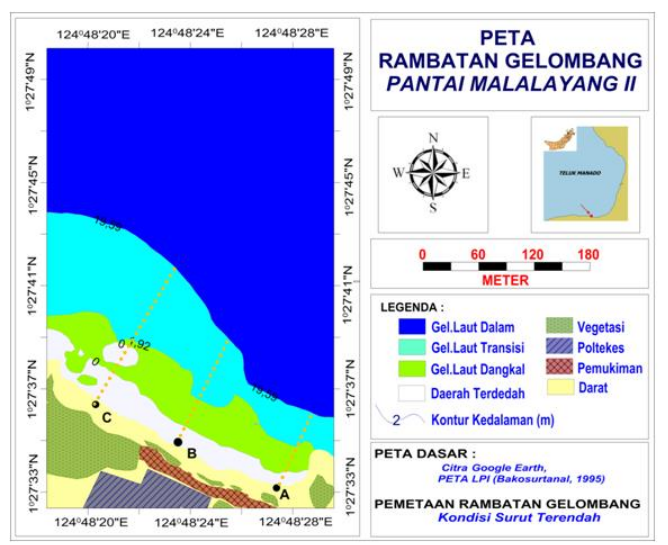

Gambar 9. Rambatan gelombang saat surut terendah (LWL) musim peralihan II (Data ECMWF 2012-2016).

Pada Gambar 10 dapat dijelaskan kerja gelombang yang merambat dari laut dalam, saat memasuki laut transisi dasar gelombang akan bergesekan dengan dasar perairan dimulai pada kedalaman 19,23 m dengan panjang gelombang $38,47 \mathrm{~m}$ dan periode 7,02 detik, sedangkan pergesekan atau proses refraksi yang terjadi dimulai dari kedalaman 1,92 $\mathrm{m}$ dengan panjang gelombang 17,03 $\mathrm{m}$ dan periode 7,84 detik. Saat pasang tertinggi di musim Peralihan I, gelombang mulai mengalami refraksi dimulai dari kedalaman 20,54 $\mathrm{m}$, dengan panjang gelombang 41,07 $\mathrm{m}$ dan periode 7,26 detik, sedangkan di laut dangkal dimulai dari kedalaman 2,05 m dengan panjang gelombang $18,79 \mathrm{~m}$ dan periode 8,37 detik. Jarak garis kedalaman perairan saat gelombang mulai bergesekan dengan dasar perairan di laut transisi dan laut dangkal ke garis pesisir memiliki jarak yang berbeda-beda di setiap wilayah yaitu pada profil A sejauh $22 \mathrm{~m}$ dan $94 \mathrm{~m}$, profil B sejauh 23 dan $123 \mathrm{~m}$, profil C 29 dan 179 m (Gambar 11).

Rambatan gelombang saat memasuki wilayah laut transisi pada musim Peralihan II disaat pasang tertinggi akan mengalami proses refraksi yang dimulai pada kedalaman $20,11 \mathrm{~m}$ dengan panjang gelombang $40,23 \mathrm{~m}$ dan periode 5,28 detik.
Tabel 5. Jarak rambatan gelombang dari laut transisi ke garis pesisir saat pasang tertinggi (Data ECMWF 20122016).

\begin{tabular}{lcccc}
\hline $\begin{array}{l}\text { Kategori } \\
\text { Musim }\end{array}$ & $\mathrm{P}$ & $\begin{array}{c}\text { L. D } \\
(\mathrm{m})\end{array}$ & $\begin{array}{r}\text { L.T } \\
(\mathrm{m})\end{array}$ & $\begin{array}{r}\text { L.D dan } \\
\text { L.T }(\mathrm{m})\end{array}$ \\
\hline Musim & $\mathrm{A}$ & 19 & 92 & 73 \\
Utara & $\mathrm{B}$ & 20 & 30 & 110 \\
& $\mathrm{C}$ & 28 & 72 & 144 \\
Musim & $\mathrm{A}$ & 22 & 94 & 72 \\
Peralihan & $\mathrm{B}$ & 23 & 32 & 109 \\
I & $\mathrm{C}$ & 29 & 79 & 150 \\
Musim & $\mathrm{A}$ & 20 & 93 & 73 \\
Peralihan & $\mathrm{B}$ & 20 & 32 & 112 \\
II & $\mathrm{C}$ & 30 & 76 & 146 \\
Rata-rata & & 19 & 09 & 90 \\
\hline
\end{tabular}

Lebih lanjut di wilayah laut dangkal dimulai di kedalaman 2,01 m dengan panjang gelombang 18,22 m dan periode 8,22 detik. Berdasarkan Gambar 12 dapat dijelaskan jarak kedalaman antara laut transisi dan laut dangkal ke garis pesisir di setiap profil yaitu pada profil A sejauh $20 \mathrm{~m}$ dan 93 $\mathrm{m}$, profil B sejauh $20 \mathrm{~m}$ dan $132 \mathrm{~m}$, profil $\mathrm{C}$ sejauh $30 \mathrm{~m}$ dan $176 \mathrm{~m}$, dari ke tiga profil penarikan jarak tersebut didapat jarak rata-rata rambatan gelombang laut transisi ke garis pesisir yaitu sejauh 133,66 m. sedangkan di laut dangkal sejauh 23,33 m, dan jarak antara ke dua garis (laut transisi dan dangkal) yaitu diprofil A sejauh $73 \mathrm{~m}, \mathrm{~B}$ sejauh $112 \mathrm{~m}$, profil $\mathrm{C}$ sejauh $146 \mathrm{~m}$, dan didapat jarak rata-ratanya sejauh 110,33 m pada Tabel 5.

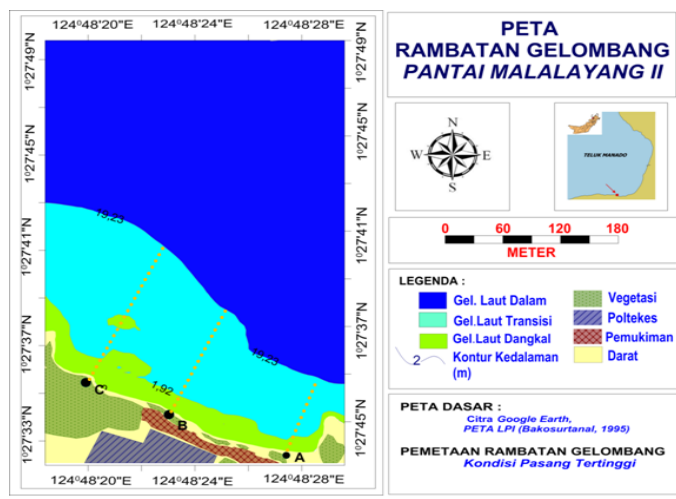

Gambar 10. Rambatan gelombang saat pasang tertinggi (HWL) musim utara (Data ECMWF 2012-2016) 


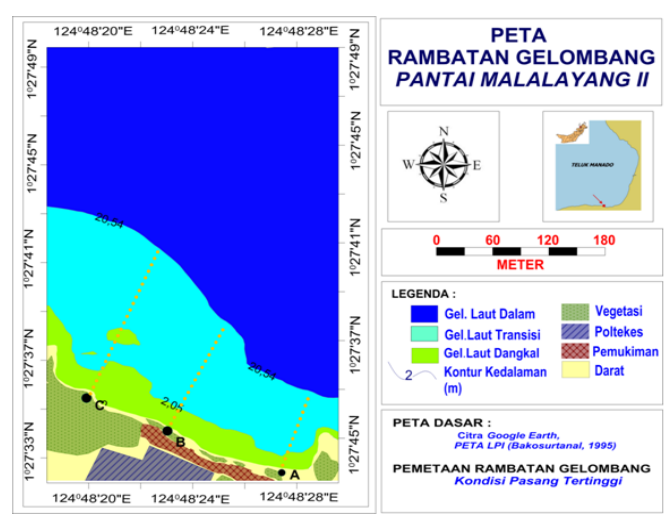

Gambar 11. Rambatan Gelombang saat pasang tertinggi (HWL) musim peralihan I (Data ECMWF 2012-2016)

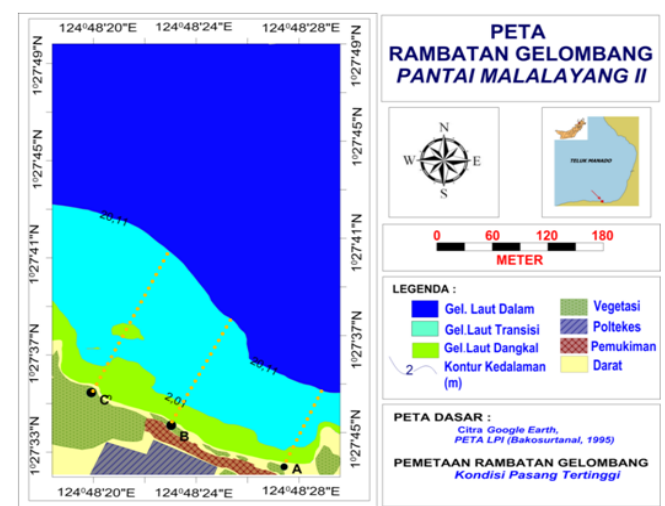

Gambar 12. Rambatan gelombang saat pasang tertinggi (HWL) musim peralihan II (Data ECMWF 2012-2016).

Hasil analisis tinggi gelombang signifiakan tahun 2012-2016 diuraikan berdasarkan musim. Pada musim Utara yaitu bulan Desember-Februari tinggi gelombang signifikan yang sering terjadi tergolong dalam kategori $\mathrm{G} \quad(>1,50-1,75 \mathrm{~m})$ dengan nilai kumulatifnya yaitu $100 \%$. Tinggi gelombang signifikan yang sering terjadi pada musim Peralihan I yaitu bulan Maret-Mei termasuk dalam kategori $\mathrm{H}(>1,75 \mathrm{~m})$ dengan nilai kumulatifnya $22,2 \%$. Di musim Selatan yaitu bulan Juni-Agustus tinggi gelombang signifikan yang kebanyakan terjadi tergolong dalam kategori $A \quad(0-0,25 \mathrm{~m})$ dengan nilai kumulatifnya yaitu $65,2 \%$, sedangkan tinggi gelombang signifikan yang sering terjadi pada saat musim Peralihan II di bulan September-
November tergolong dalam kategori $A$ $(0-0,25 \mathrm{~m})$ dengan nilai kumulatifnya $17,4 \%$.

Berdasarkan analisis terhadap tinggi gelombang signifikan yang terjadi di Teluk Manado, dimana daerah Pantai Malalayang II memiliki kerentanan terhadap aksi laut khususnya gelombang, utamanya terjadi pada saat musim Utara dan awal musim peralihan I. Kejadian gelombang dengan tinggi di atas $1 \mathrm{~m}$ umumnya terjadi saat musim ini dan bertolak dari arah rambatannya, gelombang tersebut mengarah pada kawasan Pantai Malalayang II.

Periode gelombang yang sering terjadi di daerah Teluk Manado, termasuk perairan Pantai Malalayang II diuraikan dalam keadaan musim di kawasan tersebut. Lebih lanjut pada musim Utara periode gelombang yang tercepat tergolong dalam kategori $F$ (>8-9 detik) dengan nilai kumulatifnya $21,1 \%$ dan periode gelombang terlambat tergolong dalam kategori $\mathrm{G}$ (>9-10 detik) dengan dengan nilai kumulatifnya $19,8 \%$, sedangkan di musim Peralihan I periode gelombang yang terjadi sudah berbeda pada saat musim Utara atau lebih cepat yaitu tergolong dalam kategori $\mathrm{E}$ (>7-8 detik) dengan nilai kumulatifnya $12,3 \%$, dan periode gelombang tergolong dalam kategori $\mathrm{H}$ (>10 detik) dengan nilai kumulatifnya $12 \%$. Berikut ini yaitu pada musim Selatan periode gelombang yang tercepat dari musimmusim sebelumnya, dan tergolong dalam kategori $\mathrm{B}$ ( $>4-5$ detik) dengan nilai kumulatifnya $34,4 \%$, dan periode lambat termasuk dalam kategori C ( $>5$ 6 detik) dengan nilai kumulatinya $18,4 \%$, sedangkan pada saat musim Peralihan II periode gelombang yang tercepat dari semua musim dan tergolong dalam kategori A $(>9-10$ 
detik) dengan nilai kumulatifnya 25,2\% periode gelombang terlambat termasuk dalam kategori $\mathrm{H}$ (>10 detik) dengan nilai kumulatif $33,6 \%$.

\section{KESIMPULAN}

1. Bentuk konfigurasi dasar perairan Pantai Malalayang II menampilkan perbedaan seiring dengan berubahnya elevasi pasut. Saat pasang tertinggi, garis pantai (shoreline) berimpit dengan garis pesisir (coastline). Saat surut terendah garis pantai terbentuk jauh dari garis pesisir, menampilkan lahan pantai yang terdedah antara garis pantai dan garis pesisir.

2. Gelombang bekerja pada kawasan Pantai Malalayang II terjadi pada saat musim Utara, peralihan I, dan peralihan II. Terutama pada musim Utara dan awal musim peralihan I, pantai ini menerima terpaan gelombang yang kuat dengan tinggi gelombang signifikan di atas $1 \mathrm{~m}$. Gelombang signifikan dengan tinggi di atas 1,75 $\mathrm{m}$ terkadang menerpa kawasan pantai ini saat musim Utara, peralihan I, dan peralihan II, walaupun dengan frekuensi yang sangat sedikit.

3. Gelombang bekerja sangat efektif di kawasan Pantai Malalayang II saat kondisi pasang tertinggi. Aktivitas gelombang menggerus dasar perairan terjadi pada ruang yang lebih luas saat dalam kondisi pasang tertinggi, juga gelombang dapat terhempas mencapai lahan pemukiman.

\section{DAFTAR PUSTAKA}

DISHIDROS, 1984. Kepanduan Bahari Indonesia Jilid III. TNI-AL Dinas Hidro-Oseanografi. Jakarta. 851 hal

Nazir, M. 1983. Metode Penelitian. Gralia Indonesia. Jakarta. 622 hal
Sulaiman, A., Soehardi, I. 2008. Pendahuluan Geomorfologi Pantai Kuantitatif. BPPT. 67 hal.

Suyarso, 1989. Muka Laut Rata-rata dan Aplikasinya Dalam Jaringan Geodesi. Dalam : Ongkosongo O.S.R., Suyarso (Editor). Pasang Surut. LIPI (Lembaga IImu Pengetahuan Indonesia). Pusat Penelitian dan Pengembangan Oseanografi. Jakarta. Hal 192 200.

Stewart, R.H. 2008. Introduction to Physical Oceanography Department of Oceanography. Texas A R M University. Texas. P 345.

Triatmodjo, B. 2011. Rencana Bangunan Pantai. Buku Perencanaan Bangunan Pantai, DP2M Kemendikub Republik Indonesia. 327 hal. 